\title{
Correction to: A Micro-Scale Investigation of the Adsorption of Collectors on Bastnaesite
}

\author{
Jinhong Zhang ${ }^{1}$ (D) Dongbo $\mathrm{An}^{1} \cdot$ James Withers ${ }^{2}$
}

Published online: 29 August 2019

(C) Society for Mining, Metallurgy \& Exploration Inc. 2019

\section{Correction to: Mining, Metallurgy \& Exploration} https://doi.org/10.1007/s42461-019-00118-3

In the original publication of this article Fig. 7 was duplicated as Fig. 8. The original article has been corrected and Fig. 8 is now correct.

Publisher's Note Springer Nature remains neutral with regard to jurisdictional claims in published maps and institutional affiliations. 